\title{
Saprotrophic versus symbiotic strategy during truffle ascocarp development under holm oak. A response based on ${ }^{13} \mathrm{C}$ and ${ }^{15} \mathrm{~N}$ natural abundance
}

\author{
Bernd ZELLER ${ }^{1 *}$, Claude BrÉCHET ${ }^{2}$, Jean-Paul MAURICE ${ }^{3}$, François Le TACON $^{4}$ \\ ${ }^{1}$ INRA, Nancy, UR 1138, Biogéochimie des Écosystèmes Forestiers, 54280 Champenoux, France \\ 2 INRA, Nancy-Université, UMR 1137, Écologie et Écophysiologie Forestière, 54280 Champenoux, France \\ ${ }^{3}$ Groupe mycologique Vosgien, 18 bis place des Cordeliers, 88300 Neufchâteau, France \\ ${ }^{4}$ INRA, Nancy-Université, UMR 1136, Interactions Arbres Micro-Organismes, 54280 Champenoux, France
}

(Received 11 March 2008; accepted 26 May 2008)

\begin{abstract}
-
- The development of truffles in the soil is not well understood. It is not known if a direct transfer of carbohydrates takes place between the host tree and the developing ascocarps through ectomycorrhizal structures or whether sporophores become independent from their hosts after several weeks or months and are able to use dead host tissues or soil organic matter as carbon (C) and nitrogen (N) sources.

- To study saprophytic or symbiotic capacities of truffle ascocarps the natural abundance of ${ }^{15} \mathrm{~N}$ and ${ }^{13} \mathrm{C}$ in foliage, wood, fine roots, mycorrhizae, fungal sporophores and soil were determined in a truffle orchard.

- The processes of carbon and nitrogen allocation remained unchanged during the entire period of ascocarp development of Tuber melanosporum. From ${ }^{13} \mathrm{C}$ and ${ }^{15} \mathrm{~N}$ natural abundance measurements, T. melanosporum, T. brumale and T. rufum did not exhibit saprotophic strategy during ascocarp development, which is contradictory to common statements found in handbooks regarding truffle cultivation.
\end{abstract}

${ }^{13} \mathrm{C} /{ }^{15} \mathrm{~N} /$ Tuber melanosporum / Tuber brumale / Tuber rufum / ascocarps development

Résumé - Stratégie saprophyte ou symbiotique durant le développement d'ascocarpes de truffes dans une truffière à chêne vert. Une réponse basée sur l'abondance naturelle du ${ }^{13} \mathrm{C}$ et $\mathrm{du}{ }^{15} \mathrm{~N}$.

- Le développement des truffes dans le sol n'est pas encore bien compris. Les connaissances actuelles ne nous permettent pas de savoir s'il existe un transfert direct de sucres entre l'arbre hôte et les ascocarpes en développement via les structures ectomycorhiziennes, ou si les ascocarpes utilisent le carbone et l'azote directement issu de la matière organique du sol.

- Nous avons mesuré l'abondance naturelle du ${ }^{15} \mathrm{~N}$ et du ${ }^{13} \mathrm{C}$ dans le sol, les feuilles, les mycorhizes, le bois et les carpophores d'une truffière naturelle à chêne vert afin de déterminer la stratégie de la nutrition carbonée des ascocarpes.

- Les processus d'allocation du carbone et de l'azote restent identiques pendant toute la phase de développement des ascocarpes de Tuber melanosporum. De ces mesures d'abondance naturelle du ${ }^{15} \mathrm{~N}$ et du ${ }^{13} \mathrm{C}$, il apparaît que T. melanosporum, T. brumale et T. rufum ne développent pas de stratégie saprophytique pendant le développement des ascocarpes, ce qui est en contradiction avec les idées habituellement véhiculées par les manuels de trufficulture

${ }^{13} \mathbf{C} /{ }^{15} \mathbf{N} /$ Tuber melanosporum / ascocarpes / développement

\section{INTRODUCTION}

The most valuable truffles according to their aromatic and gustative qualities are two European species of Ascomycetes, Tuber magnatum Pico, the Piemont white truffle, and T. melanosporum Vittad., the Périgord black truffle or black diamond. In 2006, the Périgord black truffle could fetch $700 € / \mathrm{kg}$ on the local market of Carpentras (south-east of France). In December 2003, after a long drought period, $1 \mathrm{~kg}$ of this truffle was valued at $1500 €$ on the local market of Périgueux (south-west of France) and $3000 €$ in Paris.
Despite their renown, the life cycle of truffles is poorly known. They form ectomycorrhizae, which originate from primary monokaryotic mycelia (Paolocci et al., 2006). From ectomycorrhizae, the primary extramatricial mycelium develops in the soil and gives birth to hypogeous sporophores (ascocarps). Ascogenous heterokaryotic tissues, resulting from an unknown fertilisation process, seem to be surrounded by homokaryotic maternal tissues.

The development of Tuber sporophores in the soil is not well understood. It is not known if a direct transfer of carbohydrates takes place between the host tree and the developing ascocarps through ectomycorrhizal structures or whether sporophores become independent from their hosts after several weeks or months and are able to use dead host tissues or

* Corresponding author: zeller@nancy.inra.fr 
soil organic matter as carbon $(\mathrm{C})$ and nitrogen $(\mathrm{N})$ sources. According to several studies, the ascocarp becomes independent from the host very early (Barry et al., 1994; Callot et al., 1999; Pradel, 1914). The young ascocarp appears to develop alongside a non-mycorrhizal root and could immediately to use soil carbon sources through external mycelium independently of the mycorrhizae. In pure cultures the mycelium of T. melanosporum is able to use cellulose as a source of carbon (Mamoun and Olivier, 1991). Similarly, in pure culture the mycelium of T. melanosporum could use cellobiose, lignin, chitin and tannins as sources of carbon (Barry, 1992). During its development, the truffle ascocarp develops from its peridium external mycelium and can colonize dead cells from living roots, dead roots, other dead organic tissues or mineral structures (Callot et al., 1999). These external hyphae absorb, water, orthophosphates and simple sugars, which are then transferred inside the ascocarp (Barry, 1992; Barry et al., 1993).

However, no convincing in situ ${ }^{13} \mathrm{C}$ or ${ }^{15} \mathrm{~N}$ experiments have been carried out proving the independent saprophytic development of the truffle ascocarps. Natural abundance of ${ }^{13} \mathrm{C}$ and ${ }^{15} \mathrm{~N}$ has frequently been used to study fungal sources of carbon and nitrogen (Hobbie et al., 2001). Gebauer and Dietrich (1993) found that positive ${ }^{15} \mathrm{~N}$ values of fungal sporophores indicated that fungi can utilize organic soil nitrogen. Högberg et al. (1996) showed that ectomycorrhizae of Norway spruce and beech, collected across Europe, were 2\%o more enriched in ${ }^{15} \mathrm{~N}$ than non-mycorrhizal fine roots. Fungal sheaths were 2.4 to $6.4 \%$ enriched compared to the root core. Other studies have confirmed that sporophores of ectomycorrhizal fungi are often more enriched in ${ }^{15} \mathrm{~N}$ than sporophores of saprotrophic fungi, whereas sporophores of saprotrophic fungi are almost always enriched in ${ }^{13} \mathrm{C}$ compared to sporophores of ectomycorrhizal fungi (Hobbie et al., 1999; 2002; Kohzu et al., 1999; 2000; Taylor et al., 2003; Trudell et al., 2004). Lilleskov et al. (2002) demonstrated that isotope signatures reflect ecophysiological functions. Ectomycorrhizal fungi that utilise organic sources of nitrogen exhibit higher $\delta^{15} \mathrm{~N}$ than ectomycorrhizal species using mineral nitrogen. Emmerton et al. (2001a; 2001b) measured ${ }^{15} \mathrm{~N}$ natural abundance in ectomycorrhizal fungi growing in pure culture and using high concentrations of ammonium, nitrate or glycine. They concluded that ${ }^{15} \mathrm{~N}$ uptake was coupled with an internally fractionating process. However, Hobbie et al. (1999; 2001; 2002), Hobbie and Colpaert (2003; 2004), Hobbie et al. $(2004 ; 2005)$ considered that in natural conditions with low nitrogen availability there is no fractionation upon uptake.

Although the relative contribution of the $\mathrm{C}$ and $\mathrm{N}$ sources and the different internal processes involved in the fractionation of ${ }^{13} \mathrm{C}$ and ${ }^{15} \mathrm{~N}$ remain unclear, it appears that the analysis of natural abundance of $\mathrm{C}$ and $\mathrm{N}$ isotopes could provide insight into the respective trophic roles of saprotrophic versus ectomycorrhizal fungi (Gebauer and Taylor, 1999; Hobbie et al., 2004; 2005; Högberg et al., 1996; Kohzu et al., 1999; Taylor et al., 2003; Trudell et al., 2004; Zeller et al., 2007).

We hypothesised that the difference in $\delta^{13} \mathrm{C}$ and $\delta^{15} \mathrm{~N}$ between saprophytic and mycorrhizal fungi reflects their source of $\mathrm{C}$ and $\mathrm{N}$. The first aim was to establish in a truffle orchard
Table I. Characteristics of the soil $\left(\mathrm{A}_{1}\right.$ horizon, $\left.0-15 \mathrm{~cm}\right)$ of the Châteauvert stand (means and standard deviation, $n=5$ ).

\begin{tabular}{lcc}
\hline & Average & Standard deviation \\
\hline Clay $(<2 \mathrm{~mm}) \%$ & 23.6 & 1.45 \\
Fine silt $(2-20 \mathrm{~mm}) \%$ & 16.4 & 0.66 \\
Coarse silt $(20-50 \mathrm{~mm}) \%$ & 10.5 & 0.46 \\
Fine sand $(50-200 \mathrm{~mm}) \%$ & 25.0 & 1.74 \\
Coarse sand $(200-2000 \mathrm{~mm}) \%$ & 24.6 & 0.78 \\
Water pH & 8.5 & 0.00 \\
Total limestone \% & 41.0 & 1.14 \\
Available $\mathrm{P}_{2} 0_{5} \%$ oo & 0.02 & 0.02 \\
$\mathrm{CEC}$ cmol+/kg & 11.4 & 1.37 \\
$\mathrm{~K}^{+} \mathrm{cmol}+/ \mathrm{kg}$ & 0.15 & 0.04 \\
$\mathrm{Mg}^{++} \mathrm{cmol}+/ \mathrm{kg}$ & 0.20 & 0.03 \\
Total C \% (Carlo Erba) & 1.4 & 0.27 \\
Total N \% (Carlo Erba) & 0.2 & 0.01 \\
$\mathrm{C} / \mathrm{N}(\mathrm{Carlo}$ Erba) & 8.1 & 1.2 \\
Total C \% (Anne) & 1.6 & 0.17 \\
Total N \% (Bremmer) & 0.2 & 0.02 \\
$\mathrm{C} / \mathrm{N}($ Anne, Bremmer) & 9.7 & 0.70 \\
$\delta^{13} \mathrm{C}(\% o)$ & -26.1 & 0.67 \\
$\delta^{15} \mathrm{~N}(\%$ ) & -4.6 & 1.18 \\
\hline
\end{tabular}

of holm oaks in the south east of France the variations in the natural abundance of ${ }^{13} \mathrm{C}$ and ${ }^{15} \mathrm{~N}$ of hypogeous sporophores formed by Tuber melanosporum, T. brumale and T. rufum, and other components of the ecosystem (epigeous ectomycorrhizal fungi, mycorrhizae, saprotrophic fungi, leaves and wood of holm oak, and soil). Using these information's the final aim was to determine the saprophytic or symbiotic capacities of truffle ascocarps.

\section{MATERIAL AND METHODS}

\subsection{Field sampling}

Samples were collected at Châteauvert, Visan, Vaucluse, France, in a holm oak truffle orchard (longitude: $4.916^{\circ} \mathrm{E}$, latitude: $\left.44.366^{\circ} \mathrm{N}\right)$. The altitude of the Châteauvert site is $200 \mathrm{~m}$, the annual winter-dominant rainfall is $759 \mathrm{~mm}$ and the mean annual temperature $13^{\circ} \mathrm{C}$. Meteorological data were provided by a meteorological station (Météo France) located near the site.

The bedrock consists of calcareous alluvial deposits. The soil is a deep brown calcarisol with a sandy-silty texture, high alkaline $\mathrm{pH}_{\text {(water) }}(8.5)$ and a limestone content of $41 \%$ (Tab. I). It is very low in available phosphorus and moderate in available $\mathrm{K}$ and $\mathrm{Mg}$. It is a highly granular and aerated free-draining soil. Each year, the site is superficially ploughed (10 to $15 \mathrm{~cm}$ deep) and irrigated $(100 \mathrm{~mm}$ of water supplied in summer).

The holm oak (Quercus ilex L.) stand $\left(10000 \mathrm{~m}^{2}\right)$ was planted in 1976 on a vineyard site. The seedlings were naturally mycorrhizal with $T$. melanosporum and other naturally occurring ectomycorrhizal fungi.

In 2002, five trees which had been observed to have produced T. melanosporum ascocarps over many years were selected for sampling. Leaves, fine roots, branches, mycorrhizae, soil samples and Tuber ascocarps were collected in August 2002 (summer) and January 2003 (winter) underneath these five trees. In January 2003, 
sporophores of epigeous fungi were also collected throughout the site.

In August 2002, non mature ascocarps of three Tuber hypogeous ectomycorrhizal fungi, T. melanosporum Vittad., T. brumale Vittad. and T. rufum Pico were located underneath the five selected trees by observing the cracks at the surface of the soil or by using a well trained dog. In January 2003, ripe ascocarps of T. melanosporum were all located by sniffing using the same well trained dog. The mature or non mature ascocarps were carefully retrieved from the soil using a small scratcher. Sporophores of eight epigeous fungi, two saprotrophic species (Stereum hirsutum (Willd.) Pers. and Tubaria hiemalis, var. hiemalis Romagn. ex. Bon) and six ectomycorrhizal species, (Clavulina cristata (Bull.) J. Schröt., Russula maculata Quél. \& Roze, Russula pallidopsora J. Blum ex Romagn., Inocybe fastigiata (Schaeff.) Quél., Amanita strobiliformis Paulet ex Vittad. and Xerocomus porosporus Imler) were collected at random on the plot. Among the two saprotrophic fungi, S. hirsutum developed on dead wood and $T$. hiemalis developed mainly on the soil. Traditional mycological identification methods were used for taxonomic determination of the hypogeous sporophores collected underneath the five selected trees and the epigeous sporophores collected throughout the site (Courtecuisse, 2000).

Twenty leaves of the year were collected all around the crown in the upper part of each tree and pooled in order to have one sample per tree. Leaves visibly contaminated by insects or fungi were eliminated. One hundred grams of soil (A1 horizon, 0-15 cm) and $5 \mathrm{~g}$ of fresh fine roots $(\leqslant 2 \mathrm{~mm}$ diameter) were collected underneath each tree. Fine roots, mycorrhizae and soil were sampled from a $0.25 \mathrm{~m}^{2}$ plot in the A1 horizon $(0-15 \mathrm{~cm})$ at equal distance from the trunk to the edge of the crown underneath each tree. Five samples of dead branches (diameter $>10 \mathrm{~cm}$ ) not still colonized by fungi were collected throughout the stand.

Oak fine roots ( $\leqslant 2 \mathrm{~mm}$ diameter) and mycorrhizae were carefully retrieved from the soil using a small scratcher, washed in water under a dissecting microscope and treated with chlorhydric acid $(\mathrm{HCl})$ in order to eliminate calcium carbonate and to only get the ${ }^{13} \mathrm{C}$ natural abundance of organic matter. For some fine root samples, the bark was carefully separated from the central cylinder using a scalpel. Mycorrhizae were tentatively identified by morphotyping on the basis of colour, mantle shape, surface texture and the presence of cystidia. They belonged mainly to the Inocybe, Amanita and Suillus genera. Tuber mycorrhizae were extremely rare despite the proximity of $\mathrm{Tu}$ ber ascocarps. It was not possible to get sufficient material for each type of mycorrhizae. The samples used for isotopic analysis were a mixture of Inocybe, Amanita, Suillus and Tuber mycorrhizae. For isotopic analysis, like fine roots or mycorrhizae, soil samples were treated with chlorhydric acid in order to avoid the signal of calcium carbonate and to only get the ${ }^{13} \mathrm{C}$ natural abundance of the organic matter.

There were four or five replicates for each type of material (leaves, fine roots, mycorrhizae, wood, soil or sporophores). The samples were first air-dried, then dried at $60{ }^{\circ} \mathrm{C}$ for $48 \mathrm{~h}$ and ground to a fine powder using a shaker with an agathe mortar and agathe beads. After cleaning, elimination of sporophores contaminated by worms, drying and grinding, 63 fungal samples were kept for stable isotope analysis: 28 Tuber samples and 35 other fungal samples. With the exception of $S$. hirsutum, each sample of Basidiomycetes submitted to analysis comprised several different sporophores including the stipe, cap and gills. The small, wavy, leathery shelves of S. hirsutum were carefully detached from the dead branches and mixed together. Tuber ascocarps were individually subjected to analysis.

Forty-four other samples (leaves, fine roots, mycorrhizae and soils) were subjected to isotopic analysis.

\subsection{Soil analysis}

Soil samples (A1 horizon, 0-15 cm) were gathered underneath the five selected trees as previously described and analysed. The variables were: particle size distribution using wet sieving and flotationsedimentation (Robinson method); organic C content was measured using a wet oxidation method (Anne, 1945); total N content was measured by the Kjeldahl method (Bremmer, 1960); pH (soil:water ratio $=1: 25$ ); cationic saturation and cationic exchange capacity were measured using 0.5 $\mathrm{M} \mathrm{NH}_{4} \mathrm{Cl}$ (Rouiller et al., 1980); "available" phosphorus was extracted consecutively with $0.004 \mathrm{~N} \mathrm{H}_{2} \mathrm{SO}_{4}$ and $0.02 \mathrm{~N}$ $\mathrm{NaOH}$ (Duchaufour and Bonneau, 1959).

\subsection{Greenhouse samples}

In order to obtain well-identified Tuber mycorrhizae, we used one-year-old holm-oak seedlings artificially inoculated with T. melanosporum in containers $(300 \mathrm{~mL})$ with a peat and vermiculite substrate added to calcium carbonate $\left(\mathrm{pH}_{(H 2 O)}\right.$ 8.05). Each seedling was inoculated with $1 \mathrm{~g}$ of fresh $T$. melanosporum ascocarp crushed with sand and suspended in $100 \mathrm{~mL}$ of water. The suspension containing spores was mixed with $300 \mathrm{~mL}$ of substrate in a cement mixer. Seedlings were grown in a greenhouse $(16 \mathrm{~h}$ photoperiod of $50 \mathrm{Wm}^{-2}$, day-night temperatures $20-24{ }^{\circ} \mathrm{C}$ ) for one year (February 2003 to February 2004).

Mycorrhizae and fine roots ( $\leqslant 2 \mathrm{~mm}$ diameter) were collected individually under a dissecting microscope in February 2004, washed and treated with chlorhydric acid in order to eliminate calcium carbonate. Tuber mycorrhizae were initially sorted to genus level on the basis of colour, mantle shape, surface texture and presence of cystidia. Mycorrhizae were then confirmed as being associated with T. melanosporum using molecular methods. Genomic DNA was extracted by using the DNeasy Mini Kit (Qiagen SA, Courtabœuf, France) following the manufacturer's instructions. Polymerase chain reactions "PCR" were performed with ITS1f (Gardes and Bruns, 1993) and ITS4 primers (White et al., 1990). Amplification reactions were performed in a PE9700 thermal cycler (Perkin-Elmer, Applied Biosystems) in a $25 \mu \mathrm{L}$ reaction mixture using the following final concentrations or total amounts: $5 \mathrm{ng}$ DNA, $1 \times$ PCR buffer $(20 \mathrm{mM}$ Tris/ $\mathrm{HCl} \mathrm{pH} 8.4$, $50 \mathrm{mM} \mathrm{KCl}), 1 \mu \mathrm{M}$ of each primer, $2.5 \mathrm{mM} \mathrm{MgCl}_{2}, 0.25 \mathrm{mM}$ of each dNTP, 0.5 unit of Taq polymerase (Promega). Amplification was conducted under the following conditions: an initial denaturation at $95{ }^{\circ} \mathrm{C}$ for $3 \mathrm{~min}$, followed by 30 cycles of denaturation at $94^{\circ} \mathrm{C}$ for $30 \mathrm{~s}$, annealing at $50{ }^{\circ} \mathrm{C}$ for $45 \mathrm{~s}$ and extension at $72{ }^{\circ} \mathrm{C}$ for $2 \mathrm{~min}$ for each cycle. The last cycle was followed by a final extension at $72{ }^{\circ} \mathrm{C}$ for $10 \mathrm{~min}$. PCR products were resolved on a $1.0 \%$ agarose gel and visualized by staining with ethidium bromide. For sequencing, the PCR products were purified with a MultiScreenTM PCR kit (Millipore, Molsheim, France) and quantified with a Low DNA Mass Ladder (Invitrogen, Cergy Pontoise, France) by electrophoresis on a $1.0 \%$ agarose gel. Sequencing was performed in CEQ 2000 DNA Analysis System (Beckman, Fullerton, CA) in the INRA Centre of Nancy (France) according to manufacturer's protocol. Similarities of ITS 
Table II. Total C, total $\mathrm{N}, \delta^{13} \mathrm{C}$ and $\delta^{15} \mathrm{~N}$ in leaves, fine roots, mycorrhizae and dead wood of Quercus ilex L. in the Châteauvert stand (means and standard deviation, $n=5$ )

\begin{tabular}{|c|c|c|c|c|c|}
\hline Sampling date & Material & $\begin{array}{c}\mathrm{C} \\
(\%)\end{array}$ & $\begin{array}{c}\mathrm{N} \\
(\%)\end{array}$ & $\begin{array}{l}\delta^{13} \mathrm{C} \\
(\% o)\end{array}$ & $\begin{array}{l}\delta^{15} \mathrm{~N} \\
(\% 0)\end{array}$ \\
\hline \multirow[t]{4}{*}{ August 2002} & Leaves & $53.5(4.46)$ & $1.3(0.26)$ & $-29.7(0.75)$ & $1.6(0.91)$ \\
\hline & Fine roots (bark) & $54.2(2.29)$ & $0.8(0.08)$ & $-27.4(0.75)$ & $2.0(1.09)$ \\
\hline & Fine roots (central cylinder) & $51.3(4.42)$ & $0.6(0.06)$ & $-26.6(0.94)$ & $3.7(0.91)$ \\
\hline & Mycorrhizae & $36.1(1.99)$ & $3.3(0.19)$ & $-26.3(0.39)$ & $3.2(0.46)$ \\
\hline \multirow[t]{2}{*}{ January 2003} & Leaves & $49.4(0.47)$ & $1.4(0.37)$ & $-30.0(0.57)$ & $-1.6(1.10)$ \\
\hline & Dead wood & $47.9(0.82)$ & $0.1(0.03)$ & $-22.7(0.13)$ & $0.6(0.67)$ \\
\hline
\end{tabular}

sequences in GenBank database were determined by using BLAST (NCB).

Five leaves were collected on each tree and mixed together. There were five replicates for each type of material (leaves, fine roots and $T$. melanosporum mycorrhizae). All samples were first air- dried, then dried at $60^{\circ} \mathrm{C}$ for $48 \mathrm{~h}$ and ground to a fine powder using a shaker with an agathe mortar and agathe beads. Fifteen samples (leaves, fine roots and mycorrhizae) were subjected to isotopic analysis. Together with the field samples a total of 123 samples were subjected to isotopic analysis.

\subsection{Isotopic analysis}

Percentages of $\mathrm{C}$ and $\mathrm{N}$ plus isotopic composition were determined in the INRA centre of Nancy-Champenoux using an online continuous flow CN analyser (Carlo Erba NA 1500) coupled with an isotope ratio mass spectrometer (Finnigan delta $S$ ). Values were reported using the standard notation $\left(\delta^{13} \mathrm{C} \% 0\right.$ and $\left.\delta^{15} \mathrm{~N} \% 0\right)$ relative to Pee-Dee Belemnite for C, using PEF (IAEA-CH-7) as a standard, and relative to atmospheric $\mathrm{N}_{2}$ for $\mathrm{N}$, using $\left(\mathrm{NH}_{4}\right)_{2} \mathrm{SO}_{4}$ (IAEA-N-1) as a standard. $\left.\delta X=\left(R_{\text {sample }} / R_{\text {standard }}\right)-1\right) \times 1000$, where $R$ is the molar ratio heavy $X /{ }^{\text {light }} X$.

\subsection{Statistical analysis}

All data sets $\left(\mathrm{C}, \mathrm{N}, \delta^{15} \mathrm{~N}, \delta^{13} \mathrm{C}\right)$ were first tested separately for normal distribution and homogeneity of variances. The analysis of variance for experimental data was conducted using the Sigmastat 3.0 software. Student's t-tests were employed to test for significant differences between saprotrophic and ectomycorrhizal fungi, and OneWay-ANOVA for differences among the different species. When effects of groups on the dependent variables were significant at the 0.05 level, the least-significant difference test $\left(\mathrm{LSD}_{0.05}\right)$ was used to compare means. When mean values of groups or species are given the standard deviation is mentioned in brackets.

\section{RESULTS}

\subsection{Field experiment}

\subsubsection{Total C and total $N$ (Tabs. I and II)}

The soil in Châteauvert is low in organic matter. The total C content averaged from $1.4 \%$ to $1.6 \%$ according to the method used (Carlo Erba NA1500 or Anne). The average total N content was $0.17 \%$ according to the two methods used (Carlo Erba NA1500 or Kjeldahl) (Tab. I) and the $\mathrm{C} / \mathrm{N}$ ratio was 8.

For the trees under field conditions, the total $\mathrm{N}$ content was significantly lower in fine roots than in leaves and significantly higher in mycorrhizae than in fine roots or leaves.

\subsection{2. $\delta^{13} C$ (Tabs. I and II, Fig. 1a)}

Under field conditions, the $\delta^{13} \mathrm{C}$ values of living oak leaves did not differ statistically between the summer (average $-29.7 \%$ ) and the winter (average $-30.0 \%$ ). $\delta^{13} \mathrm{C}$ was significantly higher in leaves that in fine roots, but did not statistically differ between fine roots and mycorrhizae. In soil ( $\mathrm{A}_{1}$ horizon), $\delta^{13} \mathrm{C}$ varied between $-25.3 \% 0$ and $-27.1 \%$ (average $-26.1 \%$ ). Dead wood of Holm-oak displayed a very different $\delta^{13} \mathrm{C}(-22.7 \%$ ) from A1 horizon.

\subsection{3. $\delta^{15} N$ (Tabs. I and II, Fig. 1a)}

Under field conditions, the average $\delta^{15} \mathrm{~N}$ values of Quercus ilex leaves were statistically identical in the summer and the winter $(-1.6 \%)$ ). $\delta^{15} \mathrm{~N}$ was significantly higher in fine roots and mycorrhizae than in leaves. $\delta^{15} \mathrm{~N}$ displayed positive values in root bark $(2.0 \%)$, in root central cylinder $(3.7 \%$ ) and in naturally-occurring mycorrhizae (3.2\%). Dead wood of holm-oak also displayed a positive $\delta^{15} \mathrm{~N}(0.6 \% 0)$. $\delta^{15} \mathrm{~N}$ remained highly negative in the A1 horizon of the soil (average $-4.6 \%$ ).

\subsubsection{Total carbon, total nitrogen, $\delta^{13} \mathrm{C}$ and $\delta^{15} \mathrm{~N}$ of sporophores (Tab. III, Figs. $2 a, 2 b, 2 c$, and Fig. 3)}

In January 2003, the average concentration of total C and total $\mathrm{N}$ of sporophores was respectively $41.7 \%$ and $3.2 \%$ respectively. The total nitrogen concentration ranged from $1.1 \%$ to $5.6 \%$ and the carbon concentration from $39.6 \%$ to $44.0 \%$. Total $\mathrm{N}$ and total $\mathrm{C}$ could not be used to differentiate between saprotrophic fungi and ectomycorrhizal fungi. The two saprotrophic fungi displayed a total $\mathrm{N}$ concentration ranging from $1.1 \%$ (S. hirsutum) to $4.6 \%$ (T. hiemalis), while ectomycorrhizal fungi displayed a total $\mathrm{N}$ concentration ranging from $2.0 \%$ ( $R$. pallidospora) to $5.6 \%$ (A. strobiliformis). 

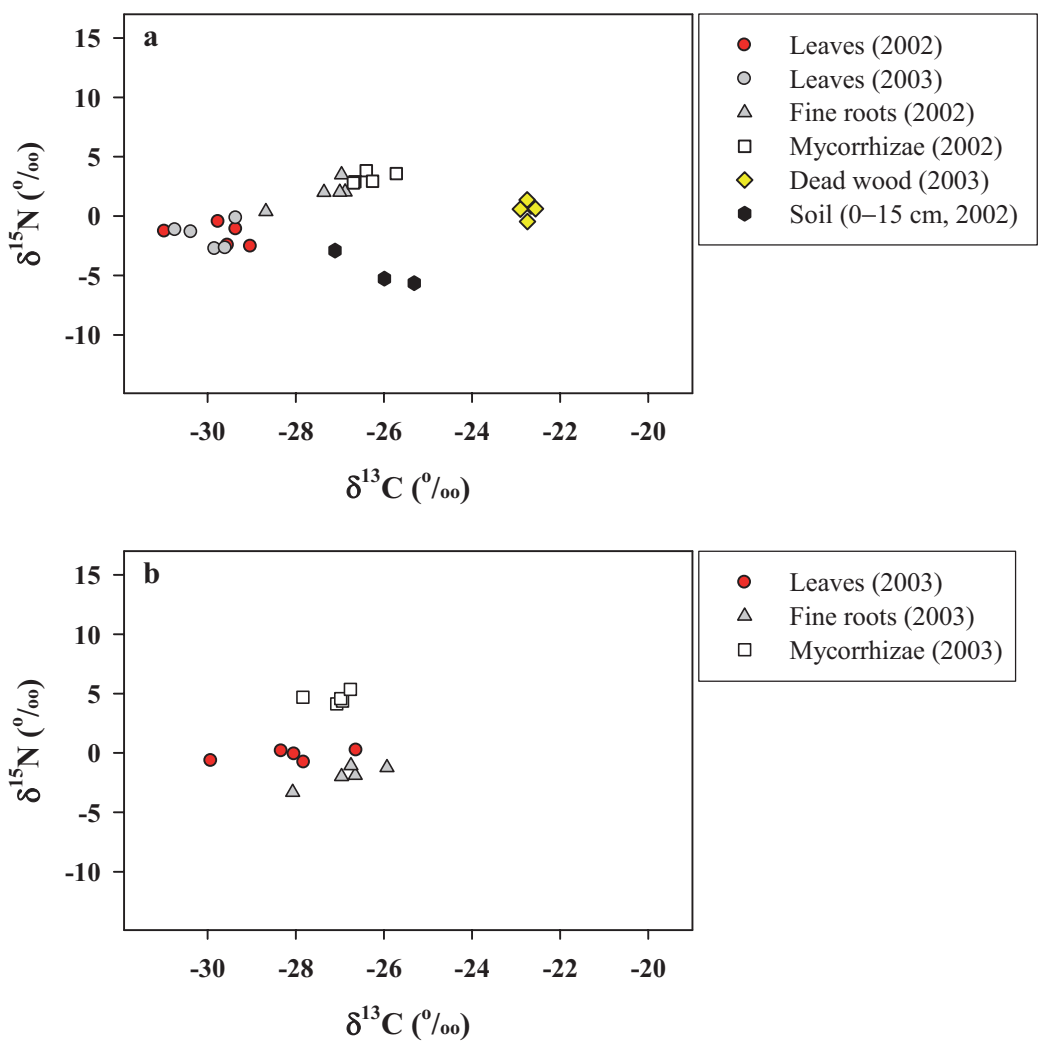

Figure 1. (a) Discrimination among leaves, fine roots, mycorrhizae, dead wood of Quercus ilex L. harvested in 2002 or 2003 and soil sampled in 2002, Châteauvert stand, according to $\delta^{13} \mathrm{C}$ and $\delta^{15} \mathrm{~N}$ (individual values, average and standard deviation for each type of material). There were no statistically significant differences for $\delta^{13} \mathrm{C}$ and $\delta^{15} \mathrm{~N}$ between fine roots and mycorrhizae, or between leaves harvested in 2002 and 2003. $\delta^{13} \mathrm{C}$ differed significantly $(P<0.001)$ between leaves and fine roots or mycorrhizae, while $\delta^{15} \mathrm{~N}$ did not. $\delta^{13} \mathrm{C}$ of dead wood differed significantly from all the other values $(P<0.001)$. (b) Discrimination among leaves, fine roots and mycorrhizae of one-year-old seedlings of Quercus ilex L. inoculated with T. melanosporum (nursery experiment 2003-2004) according to $\delta^{13} \mathrm{C}$ and $\delta^{15} \mathrm{~N}$ (individual values, average and standard deviation for each organ). $\delta^{15} \mathrm{~N}$ differed significantly between mycorrhizae and leaves or fine roots $(P<0.001)$.

Among the three Tuber species, T. rufum displayed a significantly lower total $\mathrm{N}$ concentration (3.2\%) than the two others, T. melanosporum (4.4\%) and T. brumale (4.8\%).

The immature sporophores of T. melanosporum, cropped in August, showed no significant differences in total $\mathrm{N}$ and total C compared to mature sporophores cropped in January.

$\delta^{13} \mathrm{C}$ and $\delta^{15} \mathrm{~N}$ of sporophores differed significantly between the two saprotrophic fungi and the nine ectomycorrhizal fungi $(P<0.001)$.

The two saprotrophic sporophores displayed $\delta^{13} \mathrm{C}$ values ranging from $-24.2 \%$ (T. hiemalis) to $-20.3 \%$ (S. hirsutum), while the sporophores of ectomycorrhizal fungi displayed $\delta^{13} \mathrm{C}$ values ranging from $-24.6 \%$ (Inocybe fastigiata) to $26.3 \% 0$ (Russula maculata). The $\delta^{15} \mathrm{~N}$ of the sporophores displayed a more striking difference between the two groups. The sporophores of the two saprotrophic fungi displayed a negative $\delta^{15} \mathrm{~N}$ ( $-1.1 \%$ o for $S$. hirsutum and $-4.4 \%$ o for T. hiemalis), while all of the sporophores of ectomycorrhizal fungi displayed a positive $\delta^{15} \mathrm{~N}$, ranging from $2.0 \%$ (I. fastigiata) to 13.6\% (A. strobiliformis). Among the three Tuber species, T. rufum sporophores had a significantly less negative $\delta^{13} \mathrm{C}$ than the two others and a significantly higher $\delta^{15} \mathrm{~N}$. The im- mature sporophores of T. melanosporum, cropped in August, showed no significant differences in $\delta^{15} \mathrm{~N}$ and $\delta^{13} \mathrm{C}$ compared with the mature sporophores cropped in January.

\subsection{5. $\delta_{\mathrm{CN}}$ index (Tab. III)}

Hobbie et al. (2001) proposed a combined isotopic index $\delta_{\mathrm{CN}}=\delta^{13} \mathrm{C}-\delta^{15} \mathrm{~N}$ to separate ectomycorrhizal from saprotrophic fungi. In the Châteauvert stand, the two saprotrophic fungi displayed a $\delta_{C N}$ less than $20 \%$, while all symbiotic fungi displayed values greater than $25 \%$.

\subsection{Greenhouse experiment}

\subsubsection{Total N (Tab. IV)}

Total $\mathrm{N}$ in leaves was higher under greenhouse conditions than under field conditions (1.9\% and $1.4 \%$ respectively). However, the variations between the different organs were similar under both conditions. 

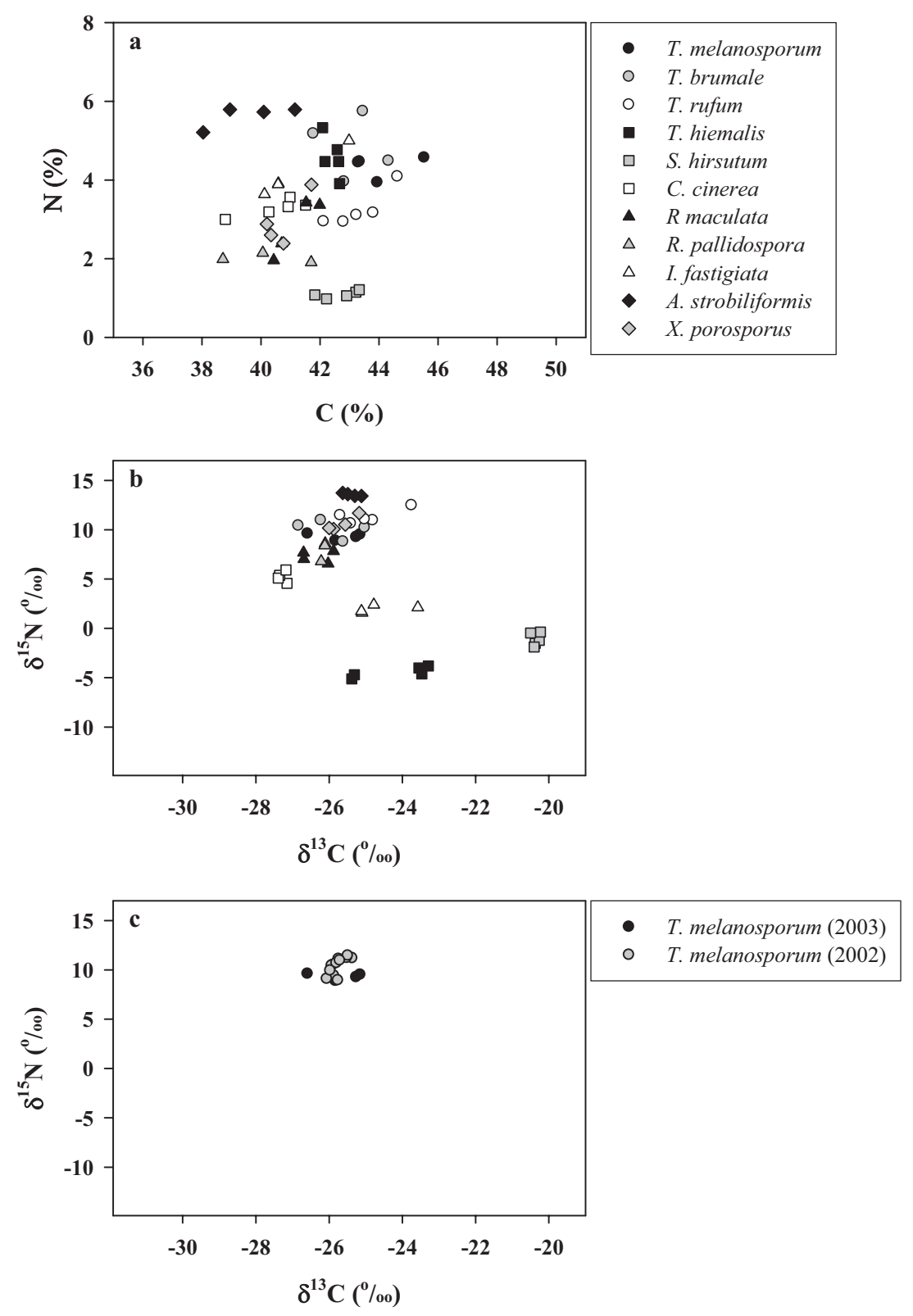

Figure 2. Discrimination among sporophores collected in the Châteauvert stand in 2003 according to: (a) Total C and total N (all sporophores, average and standard deviation for each species). Two species differed significantly $(P<0.001)$ from the other species for total N, A strobiliformis (high values) and $S$. hirsutum (low values). No significant differences were observed between saprotrophic and ectomycorrhizal fungi. ((b) $\delta^{13} \mathrm{C}$ and $\delta^{15} \mathrm{~N}$ (all sporophores, average and standard deviation for each species). Saprotrophic and ectomycorrhizal fungi differed significantly for $\delta^{15} \mathrm{~N}(P<0.001)$. I. fastigiata displayed an intermediary position. S. hirsutum differed significantly for $\delta^{13} \mathrm{C}$ from all of the other species $(P<0.001)$. (c) Discrimination among sporophores of T. melanosporum collected in the Châteauvert stand in 2002 (summer) and 2003 (winter) according to $\delta^{13} \mathrm{C}$ and $\delta^{15} \mathrm{~N}$ (all sporophores, average and standard deviation for the two dates). There were no significant differences between the two dates.

\subsection{2. $\delta^{13} C$ (Tab. IV and Fig. 1b)}

When plants were grown under greenhouse conditions, $\delta^{13} \mathrm{C}$ of oak leaves $(-28.1 \%$ o $)$ was less negative than under field conditions $(-29.7 \%)$. Both under field and greenhouse conditions $\delta^{13} \mathrm{C}$ was more negative in leaves that in fine roots, but did not statistically differ between roots and mycorrhizae.

\subsection{3. $\delta^{15} N$ (Tab. IV and Fig. 1b)}

Under greenhouse conditions, $\delta^{15} \mathrm{~N}$ did not statistically differ between leaves and fine roots, while it was largely and significantly positive in T. melanosporum mycorrhizae (average $4.6 \%$ ) compared to leaves $(-0.2 \% 0)$ and fine roots $(-1.9 \% o)$. 
Table III. Total C, total N, $\delta^{13} \mathrm{C}, \delta^{15} \mathrm{~N}$ and isotopic index $\delta_{C N}\left(\delta^{13} \mathrm{C}-\delta^{15} \mathrm{~N}\right)$ of fungal sporophores collected in the Châteauvert stand (average and standard deviation, $n=5$ or 4 ).

\begin{tabular}{|c|c|c|c|c|c|c|c|c|}
\hline Genus & Species & Authors & Date & $\begin{array}{c}\mathrm{C} \\
(\%)\end{array}$ & $\begin{array}{c}\mathrm{N} \\
(\%)\end{array}$ & $\begin{array}{l}\delta^{13} \mathrm{C} \\
(\% o)\end{array}$ & $\begin{array}{l}\delta^{15} \mathrm{~N} \\
(\% o)\end{array}$ & $\delta_{C N}=\delta^{13} \mathrm{C}-\delta^{15} \mathrm{~N}$ \\
\hline Tuber & melanosporum & Vittad. & $08-2003$ & $43.0(3.81)$ & $4.0(0.47)$ & $-25.8(0.21)$ & $10.4(0.87)$ & $-36.16(0.73)$ \\
\hline Tuber & melanosporum & Vittad. & $01-2003$ & $44.0(1.05)$ & $4.4(0.28)$ & $-25.7(0.66)$ & $9.3(0.32)$ & $-35.0(0.78)$ \\
\hline Tuber & rufum & Pico. & $01-2003$ & $43.3(0.96)$ & $3.3(0.48)$ & $-24.9(0.75)$ & $11.3(0.71)$ & $-36.2(0.54)$ \\
\hline Tubaria & hiemalis var. hie. & Romagn. ex Bon & $01-2003$ & $42.4(0.27)$ & $4.6(0.52)$ & $-24.2(1.05)$ & $-4.4(0.53)$ & $-19.7(0.69)$ \\
\hline Stereum & hirsutum & (Willd.) Pers. & $01-2003$ & $42.7(0.65)$ & $1.1(0.09)$ & $-20.3(0.11)$ & $-1.1(0.66)$ & $-19.3(0.66)$ \\
\hline Russula & pallidospora & J. Blum ex Romagn. & $01-2003$ & $40.2(1.50)$ & $2.0(0.12)$ & $-26.1(0.06)$ & $8.2(0.98)$ & $-34.1(0.93)$ \\
\hline Inocybe & fastigiata & (Schaeff.) Quél. & $01-2003$ & $41.1(1.29)$ & $4.1(0.61)$ & $-24.6(0.73)$ & $1.9(0.37)$ & $-26.6(0.63)$ \\
\hline Amanita & strobiliformis & (Paulet ex Vittad.) Bertill. & $01-2003$ & $39.6(1.35)$ & $5.6(0.28)$ & $-25.4(0.23)$ & $13.5(0.15)$ & $-38.9(0.37)$ \\
\hline Xerocomus & porosporus & Imler & $01-2003$ & $40.8(0.68)$ & $2.9(0.66)$ & $-25.7(0.37)$ & $10.6(0.74)$ & $-36.3(0.41)$ \\
\hline
\end{tabular}

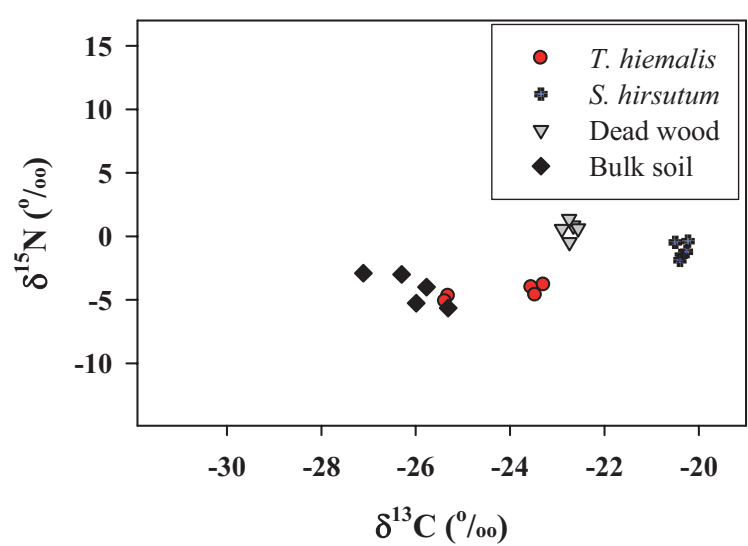

Figure 3. Discrimination among the two saprotrophic sporophores collected in the Châteauvert stand in 2003 according to $\delta^{13} \mathrm{C}$ and $\delta^{15} \mathrm{~N}$ (all sporophores, average and standard deviation). Comparison with soil and wood $\delta^{13} \mathrm{C}$ and $\delta^{15} \mathrm{~N}$. Tubaria hiemalis lives on soil and Stereum hirsutum on wood. There is a statistically significant $\delta^{13} \mathrm{C}$ shift between soil and Tubaria hiemalis and between wood and Stereum hirsutum. There is no statistically significant $\delta^{15} \mathrm{~N}$ shift between the two fungi and the two corresponding substrates.

\section{DISCUSSION}

In the Châteauvert stand, holm oak (Q. ilex) leaves displayed different $\delta^{13} \mathrm{C}$ and $\delta^{15} \mathrm{~N}$ values from those of sessile oak leaves (Quercus petraea) as obtained by Zeller et al. (2007) in the Breuil forest $(-29.7 \%$ compared to $-28.8 \%$ o and $-1.6 \%$ compared to $-4.1 \%$ ). The difference was higher still for dead wood $\left(\delta^{13} \mathrm{C}\right.$ of $-22.7 \%$ compared to $-26.4 \%$ ). Similarly $\delta^{13} \mathrm{C}$ and $\delta^{15} \mathrm{~N}$ were different in the $\mathrm{A}_{1}$ horizon of the soils in the two sites $(-26.1 \%$ and $-4.6 \%$ compared to $-28.3 \%$ and $1.4 \%$ respectively). These differences are probably partly due to soil and climatic differences between the two ecosystems. The Châteauvert stand is characterised by a Mediterranean climate and a calcareous soil, while the Breuil forest is characterised by a temperate climate and an acidic soil. Consequently, the $\mathrm{C} / \mathrm{N}$ ratio of the $\mathrm{A} 1$ horizon is less than
10 in the Châteauvert stand while it is around 20 in the same horizon of the Breuil forest.

Despite these differences in ecological conditions, $\delta^{13} \mathrm{C}$ and $\delta^{15} \mathrm{~N}$ of fungal sporophores displayed the same tendencies in the two sites. As reported by several authors (Gebauer and Taylor, 1999; Henn and Chapela, 2001; Hobbie et al., 1999, 2001; Högberg, 1997; Kohzu et al., 1999; Taylor et al., 2003, Trudell et al., 2004; Zeller et al., 2007), $\delta^{13} \mathrm{C}$ values differed between sporophores of saprotrophic and ectomycorrhizal fungi. Sporophores of the two saprotrophic fungi from the Châteauvert site showed a ${ }^{13} \mathrm{C}$ enrichment compared to their substrates. T. hiemalis displayed a $\delta^{13} \mathrm{C}$ of $-24.2 \%$ compared to $-26.1 \%$ for soil organic matter. Similarly, S. hirsutum displayed a ${ }^{13} \mathrm{C}$ of $-20.3 \%$ o compared to $-22.7 \%$ o for dead wood (Fig. 3).

Sporophores of the two saprotrophic fungi displayed no or little ${ }^{15} \mathrm{~N}$ fractionation compared to their substrate (Fig. 3). T. hiemalis displayed a $\delta^{15} \mathrm{~N}$ of $-4.4 \%$, very close to the $\delta^{15} \mathrm{~N}$ of soil organic matter $(-4.6 \%)$ ). Similarly, S. hirsutum displayed a low $\delta^{15} \mathrm{~N}$ fractionation $(-1.1 \%$ compared to $0.6 \%$ for dead wood). These results are very close to those obtained by Zeller et al. (2007) in the Breuil forest, where most saprotrophic fungi also had no or little effect on fractionation of stable $\mathrm{N}$ isotopes relative to their substrates (leaves, twigs, wood or soil).

In the Châteauvert stand, ${ }^{13} \mathrm{C}$ natural abundance of ectomycorrhizal fungi sporophores varied from $-24.6 \%$ to 27.2\%o. A similar amplitude was observed in the Breuil forest $\left(-22.2 \%\right.$ o to $-28.1 \%$ ) . According to the ${ }^{13} \mathrm{C}$ natural abundance in their sporophores, we can assume whether ECM fungi acquire more carbon from their host than from dead organic matter, or the contrary. I. fastigiata displayed a $\delta^{13} \mathrm{C}$ of $24.6 \%$, which is close to the value found in sporophores of the saprotrophic fungus $T$. hiemalis. On the other hand, $C$. cinerea displayed a $\delta^{13} \mathrm{C}$ of $-27.3 \%$. It could be hypothesised that $C$. cinerea acquires more carbon from its host than I. fastigiata. Nevertheless, according to the isotopic index $\Delta_{C N}=\delta^{13} \mathrm{C}$ $-\delta^{15} \mathrm{~N}$, I. fastigiata is an ectomycorrhizal fungus, the limit between saprotrophic and symbiotic strategies being $25.0 \%$ (Hobbie et al., 2001). Indeed, I. fastigiata displayed a $\Delta_{C N}$ of $-26.6 \%$. 
Table IV. Nursery experiment (2003). Total C, total $\mathrm{N}, \delta^{13} \mathrm{C}$ and $\delta^{15} \mathrm{~N}$ in leaves, fine roots and mycorrhizae of one-year-old seedlings of Quercus ilex L. artificially inoculated with T. melanosporum (average and standard deviation, $n=5$ ).

\begin{tabular}{|c|c|c|c|c|c|}
\hline Sampling date & Material & $\begin{array}{c}\mathrm{C} \\
(\%)\end{array}$ & $\begin{array}{c}\mathrm{N} \\
(\%)\end{array}$ & $\begin{array}{l}\delta^{13} \mathrm{C} \\
(\% o)\end{array}$ & $\begin{array}{l}\delta^{15} \mathrm{~N} \\
(\% o)\end{array}$ \\
\hline August 2002 & Fine roots & $46.5(0.72)$ & $1.4(0.27)$ & $-26.9(0.77)$ & $-1.9(0.89)$ \\
\hline
\end{tabular}

$\delta^{15} \mathrm{~N}$ natural abundance of ectomycorrhizal sporophores was much more variable than $\delta^{13} \mathrm{C}$ natural abundance. For example, I. fastigiata displayed a low nitrogen natural abundance $\left(\delta^{15} \mathrm{~N}\right.$ of $2.0 \%$ ), while A. strobiliformis displayed a high natural abundance $\left(\delta^{15} \mathrm{~N}\right.$ of $13.5 \%$ ). These results are congruent with those of several research teams (Gebauer and Dietrich, 1993, Henn and Chapela, 2001, Hobbie et al., 2004; Kohzu et al., 1999; Taylor et al., 2003; Trudell et al., 2004; Zeller et al., 2007) who all observed high ${ }^{15} \mathrm{~N}$ abundance in ectomycorrhizal fungi sporophores. The three Tuber species displayed a high $\delta^{15} \mathrm{~N}$ value $(9.3$ to $10.4 \%$ ). Hobbie et al., (2001) also found for T. gibbosum, a North American truffle, high $\delta^{15} \mathrm{~N}$ values (12.0 to $16.6 \%$ ). In the Châteauvert site, the amplitude of $\delta^{15} \mathrm{~N}$ variation among ectomycorrhizal sporophores was similar to the amplitude observed in the Breuil forest ( $-1.0 \%$ to $10.2 \%$ ). From the Châteauvert results, congruent with those of Hobbie et al. (2001) for T. gibbosum in Oregon, it seems improbable that Tuber ascocarps could use, through protease excretion, nitrogen incorporated in soil organic matter which display on average a $\delta^{15} \mathrm{~N}$ of $4.6 \%$, while T. melanosporum ascocarps display $\delta^{15} \mathrm{~N}$ values ranging on average from $9.3 \% \mathrm{o}$ in the winter to $10.4 \% \mathrm{o}$ in the summer. A transfer of nitrogen via mycorrhizae, which displayed a positive $\delta^{15} \mathrm{~N}$ (4.6\% in nursery conditions), seems much more probable. On the other hand, the saprotrophic fungus $T$. hiemalis, which displays a negative $\delta^{15} \mathrm{~N}$ similar to the $\delta^{15} \mathrm{~N}$ of the soil, probably utilises complex forms of soil organic matter for its nitrogen supply (Fig. 3).

According to Hobbie et al. (1999) and Kohzu et al. (2000), the transfer of nitrogen to trees by ectomycorrhizal fungi is a fractionating process, which could occur through amino acid biosynthesis or amino acid transfer to the host. Nevertheless, according to the Breuil results (Zeller et al., 2007), some ectomycorrhizal fungi (i.e., Lactarius) seem to have a different way of operating and either supply $\mathrm{N}$ to the host without $\mathrm{N}$ isotope fractionation or do not supply $\mathrm{N}$ to the host. Moreover, this fractioning process does not occur in all symbiotic associations. In mycoheterotrophic orchids, the host plant gain most of its nitrogen from their associated ectomycorrhizal fungi and display the same isotope signature as their fungal partner (Bidartondo et al., 2004; Gebauer and Meyer, 2003). In our nursery experiment with trees and ectomycorrhizal fungi, it is clear that the fractioning process of nitrogen started through $T$. melanosporum mycorrhizae. From $-1.9 \%$ in fine roots, $\delta^{15} \mathrm{~N}$ shifted to $4.6 \%$ in T. melanosporum mycorrhizae. A similar shift was found in the Breuil forest for Cortinarius sp. and Tricholoma sciodes mycorrhizae (Zeller et al., 2007).

From the isotopic index $\Delta_{C N}=\delta^{13} \mathrm{C}-\delta^{15} \mathrm{~N}$, which allows assignment of a mycorrhizal or a saprotrophic strategy for sporophore differentiation, it is obvious that Tuber ascocarps do not display a saprotrophic strategy. If we consider the $\delta^{13} \mathrm{C}$ values alone, the conclusions are the same as Hobbie et al. (2001) when considering that the limit between saprotrophic and symbiotic strategies is $24 \%$ (Tab. III). From the Châteauvert results, it seems that, during ascocarp differentiation, T. melanosporum, T. brumale and T. rufum behave like ectomycorrhizal fungi and not like saprotrophic fungi, despite the fact that sporophore initiation and development are rapid (some days) in ectomycorrhizal Basidiomycetes and very slow in Tuber species (six to nine months). Moreover, there were no statistically significant differences between newly formed T. melanosporum ascocarps collected in the summer (August) and mature ascocarps collected in the winter (January of the following year). This implies that the processes of carbon allocation remained identical during the entire period of $T$. melanosporum ascocarp development.

It then becomes a challenge to know to which category of ectomycorrhizal fungi the species of genus Tuber belongs. What proportion of carbon do they derive from their host when forming ectomycorrhizae? What is the importance of their saprotroph ability during ascocarp differentiation? Although we do not know enough on the relationships between isotope signatures, metabolic processes and ecosystem functions, from the results of this study, we can hypothesise that like other ectomycorrhizal fungi, which have saprotrophic capacities, Tuber species depend on their host at least partly for ascocarp development and maturation. It is difficult to believe that at any step of their development Tuber ascocarps are completely independent from their host. Prior work has shown that young ascocarps of T. melanosporum never develop if separated from their host (Rouquerolle and Payre, 1975). Rommel (1938) obtained similar results with other ectomycorrhizal fungi in Sweden. Trenching completely prevented fruit body formation of ectomycorrhizal fungi. However, some ectomycorrhizal fungi may mobilise organic polymers of nitrogen, increasing their availability to host plants (Perez-Moreno and Read, 2000; Read and Perez-Moreno, 2003). Similarly, ectomycorrhizal fungi, even if they depend on their host for carbon allocation, can also express extracellular enzyme activities in the soil. Courty et al. (2005) showed that several ectomycorrhizal fungi expressed high activities of cellobiohydrolase, $\beta$ glucosidase, chitinase, laccase, glucuronidase and xylosidase, suggesting their contribution to the degradation of soil humic polymers so as to acquire extra carbon and other nutrients from polyaromatic complexes. Callot et al. (1999) found that in mycorrhizae, T. melanosporum hyphae are able to degrade polyphenols inside dead host cells. Similarly, Tuber hyphae seem able to develop in the dead cells of root bark (Callot 
et al., 1999). From these different results or observations, it seems obvious that during Tuber sporophore differentiation, a direct transfer of hexose exists between the host and the fungus via ectomycorrhizal structures, and an indirect transfer of carbon from dead host cells or dead mycorrhizae or dead roots or exfoliating root bark via free hyphae displaying saprotrophic abilities. Nevertheless, according to Lindahl et al. (1999) and Leake (2001), ectomycorrhizal fungi do not need to produce costly ligninases to acquire nutrients from dead organic matter. Rather than direct nutrient capture, ectomycorrhizal fungi may obtain nutrients via absorption of small organic molecules exogenously decomposed by saprotrophic fungi. In two forests of southern Sweden, Staaf (1988) showed that trenching had no significant effect on total organic matter over the following six years. These results, as well as results from other similar studies, suggest that ectomycorrhizal fungi through mycorrhizae or sporophores do not play an important role in the use of soil organic matter, despite their saprotrophic abilities.

According to France and Reid (1983) and Straatsma and Bruinsma (1986), ectomycorrhizal fungi can assimilate $\mathrm{CO}_{2}$. Lapeyrie (2002) demonstrated that Paxillus involutus could utilise bicarbonate ions from solution for oxalate synthesis. Barry (1993) showed that T. melanosporum ascocarps were able to fix $\mathrm{CO}_{2}(10 \mu \mathrm{g}$ of $\mathrm{C}$ per $\mathrm{g}$ of dry matter and per hour). Lacourt et al. (2002) demonstrated the existence of an anaplerotic pathway in T. borchii mycelium and ascocarp. Ceccaroli et al. (2003) confirmed the existence of anaplerosis in $T$. borchii mycelium. Nevertheless, anaplerotic uptake of carbon is unlikely to provide a significant part of the carbon necessary for Tuber ascocarp development. Based on complete pathways analyses, Marx et al. (2001) showed that in Corynebacterium glutamicum anaplerotic reactions cannot contribute to biomass at a level greater than 3-5\% of carbon.

Our main conclusion is that, when required climatic and edaphic conditions are met, primordial initiation of T. melanosporum is strictly dependent on the host as in almost all ectomycorrhizal fungi. Soil humidity is crucial for the development of young primordia into ascocarps during the summer (Le Tacon et al., 1982). During ascocarp development, carbohydrate demand could be supplied by the host as simple carbohydrates through mycorrhizae, or by an indirect transfer of carbon from dead host tissues, or by the fruit body itself through the tufts of hyphae sprouting from the tops of the scales of the peridium (Barry et al., 1994; Callot and Guyon, 1990). These hyphae colonise the surrounding soil and can probably use complex forms of organic matter (Barry et al., 1993). There is a huge difference between epigeous ectomycorrhizal fungi which produce mature sporophores in some days and truffles which produce mature ascocarps in six or nine months. Are the mycorrhizae, which have given birth to the young Tuber primordium in May or June, still functioning in January or February of the following year when the ascocarp is mature? Does the ascocarp get its carbon from host photosynthates through mycorrhizae during all its development or only during primordium formation? Does it obtain its organic compounds both from the host and from current decomposition activities or does it completely get its carbon from dead organic matter in the final phase of maturation? From our results, it seems improbable that carbon allocation for ascocarp development could be mainly supplied via saprotrophic pathways from surrounding soil organic matter or dead host tissues, and that sporophores could be completely independent at any time during their development, even during late maturation. Our results bring new insights on truffle ascocarp development and clearly show from $\delta^{13} \mathrm{C}$ and $\delta^{15} \mathrm{~N}$ abundance that Tuber ascocarps do not exhibit a saprotrophic strategy during their development. These results contradict the statements of well recognized truffle handbooks (Callot et al., 1999; Olivier et al., 1996) and could be of some importance for the improvement of truffle cultivation methods.

However, in situ ${ }^{13} \mathrm{C}$ and ${ }^{15} \mathrm{~N}$ labelling experiments are the only way to solve the question of carbon and nitrogen allocation during Tuber sporophore differentiation. However, the technical difficulties are great, which is likely why no convincing experiments have yet been conducted. We have started some preliminary labelling experiments and we hope to obtain new results in the coming years.

Acknowledgements: For this study, we utilised the online continuous flow CN analyser (Carlo Erba NA1500) coupled with an isotope ratio mass spectrometer (Finnigan delta $S$ ) and DNA sequencing facilities at INRA-Nancy financed by INRA and the Région Lorraine. The help of René Gleyze, André Valayer and Christian Tortel is greatly appreciated. We particularly thank Christian Tortel for having allowed us to work in the Châteauvert truffle orchard. We are grateful for the useful comments of colleagues on an earlier version of the manuscript and for the corrections of Patricia Brossier. We thank the two anonymous reviewers for their comments and suggestions.

Without Oscar, a very well trained truffle hunter dog, this work would not have been possible.

\section{REFERENCES}

Anne P., 1945. Sur le dosage rapide du carbone organique des sols, Ann. Agron. 2: 161-172.

Barry D., 1992. Croissance et fonctionnement d'un ascocarpe au stade adulte de Tuber melanosporum et Tuber aestivum. Étude structurale des hyphes externes et approche expérimentale de leur fonction. Thèse de Doctorat en Sciences Agronomiques, ENSAM Montpellier, $155 \mathrm{p}$.

Barry D., Callot G., Janex-Favre M.C., Pargney J.C., and Parguey-Leduc A., 1993. Morphologie des hyphes externes observées sur le péridium des Tuber à écailles : évolution au cours du développement de l'ascocarpe. Can. J. Bot. 71: 609-619.

Barry D., Staunton S., and Callot G., 1994. Mode of the absorption of water and nutrients by ascocarps of Tuber melanosporum and Tuber aestivum. A radioactive tracer technique. Can. J. Bot. 72: 317-322.

Bidartondo M.I., Burghardt B., Gebauer G., Bruns T., and Read D., 2004. Changing partners in the dark: isotopic and molecular evidence of ectomycorrhizal liaisons between forest orchids and trees. Proc. R. Soc. 271: 1799-1806.

Bremmer J.M., 1960. Determination of nitrogen in soil by the Kjeldahl method. J. Agric. Sci. 55: 11-33.

Callot G. and Guyon A., 1990. Microstructural analysis of the truffle ascocarp interface during development. Proc. of 14th Int. Congress of Soil Science, Kyoto, Japan, pp. 256-261.

Callot G., Bye P., Raymond M., Fernandez D., Pargney J.C., PargueyLeduc A., Janex-Favre M.C., Moussa R., and Pages L., 1999. La truffe, la terre, la vie. Éditions INRA, Paris, 210 p.

Ceccaroli P., Saltarelli R., Cesari P., Pierleoni R., Saccocini C., Vallorani L., Stocchi V., and Martin F., 2003. Carbohydrate and amino acid metabolism in Tuber borchii mycelium during glucose utilization: a ${ }^{13}$ C NMR study. Fungal Genet. Biol. 39: 168-179. 
Courty P.E., Pritsch K., Schloter M., Hartmann A., and Garbaye J., 2005. Activity profiling of ectomycorrhiza communities in two forest soils using multiple enzymatic tests. New Phytol. 167: 309-319.

Courtecuisse R., 2000. Mushrooms of Britain and Europe, Harper Collins, $904 \mathrm{p}$

Duchaufour P. and Bonneau M., 1959. Une nouvelle méthode de dosage du phosphore assimilable dans les sols forestiers. Bulletin de l'Association Française d'Étude des Sols 4: 193-198.

Emmerton K.S., Callaghan T.V., Jones H.E., Leake J.R., Michelsen A., and Read D.J., 2001a. Assimilation and isotopic fractionation of nitrogen by mycorrhizal fungi. New Phytol. 151: 503-511

Emmerton K.S., Callaghan T.V., Jones H.E., Leake J.R., Michelsen A., and Read D.J., 2001b. Assimilation and isotopic fractionation of nitrogen by mycorrhizal and nonmycorrhizal subarctic plants. New Phytol. 151: 513-524.

France R.C. and Reid C.P.P., 1983. Interactions of nitrogen and carbon in the physiology of ectomycorrhizae. Can. J. Bot. 61: 964-984.

Gardes M. and Bruns T.D., 1993. ITS primers with enhanced specificity for basidiomycetes - application to the identification of mycorrhizae and rusts. Mol. Ecol. 2:113-118.

Gebauer G. and Dietrich P., 1993. Nitrogen isotope ratios in different compartments of a mixed stand of spruce, larch and beech trees and of understorey vegetation including fungi. Isotopenpraxis 29: 35-44.

Gebauer G. and Taylor A.F.S., 1999. ${ }^{15} \mathrm{~N}$ natural abundance in fruit bodies of different functional groups of fungi in relation to substrate utilization. New Phytol. 142: 93-101.

Gebauer G. and Meyer M., 2003. ${ }^{15} \mathrm{~N}$ and ${ }^{13} \mathrm{C}$ natural abundance of autotrophic and myco-heterotrophic orchids provides insight into nitrogen and carbon gain from fungal association. New Phytol. 160: 209-223.

Henn M.R. and Chapela I.H., 2001. Ecophysiology of ${ }^{13} \mathrm{C}$ and ${ }^{15} \mathrm{~N}$ isotopic fractionation in forest fungi and the roots of the saprotrophicmycorrhizal divide. Oecologia 128: 480-487.

Hobbie E.A., 2005 Using isotopic tracers to follow carbon and nitrogen cycling in fungi. In: Dighton J., White J. and Oudemans P. (Eds.), The Fungal Community: Its Organization and Role in the Ecosystem, 3rted CRC Press, pp. 361-381.

Hobbie E.A. and Colpaert J.V., 2003. Nitrogen availability and colonization by mycorrhizal fungi correlate with nitrogen isotope patterns in plants. New Phytol. 157: 115-126.

Hobbie E.A. and Colpaert J.V., 2004. Nitrogen availability and mycorrhizal colonization influence water use efficiency and carbon isotope patterns in Pinus sylvestris. New Phytol. 164: 515-525.

Hobbie E.A., Macko S.A., and Shugart H., 1999. Insights into nitrogen and carbon dynamics of ectomycorrhizal and saprotrophic fungi from isotopic evidence. Oecologia 118: 353-360.

Hobbie E.A., Weber N.S., and Trappe J.M., 2001. Mycorrhizal vs. saprotrophic status of fungi: the isotopic evidence. New Phytol. 150: 601610.

Hobbie E.A., Weber N.S., Trappe J.M., and van Klinken G.J., 2002. Using radiocarbon to determine the mycorrhizal status of fungi. New Phytol. 156: 129-136.

Hobbie E.A., Sanchez F.S., and Rygiewicz P.T., 2004. Carbon use, nitrogen use, and isotopic fractionation of ectomycorrhizal and saprotrophic fungi in natural abundance and ${ }^{13} \mathrm{C}$-labelled cultures. Mycol. Res. 108: 725-736.

Hobbie E.A., Jumpponen A., and Trappe J.M., 2005. Foliar and fungal ${ }^{15} \mathrm{~N}:{ }^{14} \mathrm{~N}$ ratios reflect development of mycorrhizae and nitrogen supply during primary succession: testing analytical models. Oecologia 146: 258-268.

Högberg P., 1997. ${ }^{15} \mathrm{~N}$ natural abundance in soil-plant systems. New Phytol. 137: 179-203.

Högberg P., Högbom L., Schinkel H., Högberg M., Johannisson C., and Wallmark H., 1996. ${ }^{15} \mathrm{~N}$ abundance of surface soils, roots and mycorrhizae in profiles of European forest soils. Oecologia 108: 207-214.

Kohzu A., Yoshioka T., Ando T., Takahashi M., Koba K., and Wada E., 1999. Natural ${ }^{13} \mathrm{C}$ and ${ }^{15} \mathrm{~N}$ abundance of field-collected fungi and their ecological implications. New Phytol. 144: 323-330.

Kohzu A., Tateishi T., Yamada A., Koba K., and Wada E., 2000. Nitrogen isotope fractionation during nitrogen transport from ectomycorrhizal fungi, Suillus granulatus, to the host plant, Pinus densiflora. J. Soil Sci. Plant Nutr. 46: 733-739.
Lacourt I., Duplessis S., Abbà S., Bonfante P., and Martin F., 2002. Isolation and characterization of differentially expressed genes in the mycelium and fruit body of Tuber borchii. Appl. Environ. Microbiol. 68: 4574-4582.

Lapeyrie F., 2002. Oxalate synthesis from soil bicarbonate by the mycorrhizal fungus Paxillus involutus. Plant Soil 110: 3-8.

Leake J.T., 2001. Is diversity of ectomycorrhizal fungi important for ecosystem function? New Phytol. 152: 1-3.

Le Tacon F., Delmas J., Gleyze R., and Bouchard D.,1982. Influence du régime hydrique du sol et de la fertilisation sur la fructification de la truffe noire du Périgord (Tuber melanosporum Vitt.) dans le sud-est de la France. Acta Oecol. 4: 291-306.

Lilleskov E.A., Hobbie E.A., and Fahey T.J., 2002. Ectomycorrhizal fungal taxa differing in response to nitrogen deposition also differ in pure culture organic nitrogen use and natural abundance of nitrogen isotopes. New Phytol. 154: 219-231.

Lindahl B., Stenlid J., Olsson S., and Finlay R., 1999. Translocation of ${ }^{32} \mathrm{P}$ between interacting mycelia of a wood decomposing fungus and ectomycorrhizal fungi in microcosm systems. New Phytol. 144: 183193.

Mamoun M. and Olivier J.M., 1991. Influence du substrat carboné et de la forme d'azote minéral sur la croissance de T. melanosporum Vittad. en culture pure. Application à la production de biomasse mycélienne. Agronomie 11: 521-527.

Marx A., de Graaf A.A., Wiechert W., Aggeling L., and Sahm H., 2000. Determination of the fluxes in the central metabolism of Corynebacterium glutamicum by nuclear magnetic resonance spectroscopy combined with metabolite balancing. Biotechnœ. Bioeng. 4: $111-129$.

Olivier J.M., Savignac J.C., and Sourzat P., 1996. Truffe et trufficulture. Éditions Fanlac, Périgueux, France, 270 p.

Paolocci F., Rubini A., Riccioni C., and ArcioniS., 2006. Re-evaluation of the life cycle of Tuber magnatum. Appl. Environ. Microbiol. 72: 2390-2393.

Perez-Moreno J. and Read D.J., 2000. Mobilization and transfer of nutrients from litter to tree seedlings via the vegetative mycelium of ectomycorrhizal plants. New Phytol. 145: 301-309.

Pradel L., 1914. Manuel de trufficulture, guide pratique. Librairie JB Baillère et Fils, Paris, 1914.

Read D.J. and Perez-Moreno J., 2003. Mycorrhizas and nutrient cycling in ecosystems - a journey towards relevance? New Phytol. 157: 475492.

Rommel L.G., 1938. A trenching experiment in spruce forest and its bearing on problems of mycotrophy. Sven. Bot. Tidsk. 32: 89-99.

Rouquerolle T. and Payre H., 1975. Conséquences de quelques particularités biologiques des Tuber sur les caractères des cultures de mycélium et sur la formation des truffes. Rev. Mycol. 29: 213-224.

Rouiller J., Guillet B., and Bruckert S., 1980. Cations acides échangeables et acidités de surface. Approche analytique et incidence pédogénétique, Bull. Assoc. Française d'Étude des Sols 2: 161-175.

Staaf H., 1988. Litter decomposition in beech forests - effects of excluding tree roots. Biol. Fertil. Soils 6: 302-305.

Straatsma G. and Bruinsma J., 1986. Carboxylated metabolic intermediates as nutritional factors in vegetative growth of the mycorrhizal mushroom Cantharellus cibarius Fr. J. Plant Physiol. 125: 377-381.

Taylor A.F.S., Fransson P.M., Högberg P., Högberg M.N., and Plamboeck A.H., 2003. Species level patterns in ${ }^{13} \mathrm{C}$ and ${ }^{15} \mathrm{~N}$ abundance of ectomycorrhizal and saprotrophic fungal sporocarps. New Phytol. 159: 757-774.

Trudell S.A., Rygiewicz P.T., and Edmonds R. L., 2004. Patterns of nitrogen and carbon stable isotope ratios in macrofungi, plants and soils in two old-growth conifer forests. New Phytol. 164: 317-335.

White T.J., Bruns T., Lee S., and Taylor J., 1990. Amplification and direct sequencing of fungal ribosomal RNA genes for phylogenetics. In: Gelfand M.A., Sninsky D.H., and White T.J. (Eds.), PCR Protocols: A guide to methods and applications, Academic Press, San Diego, CA, pp. 315-322.

Zeller B., Bréchet C., Maurice J.P., and Le Tacon F., 2007. ${ }^{13} \mathrm{C}$ and ${ }^{15} \mathrm{~N}$ isotopic fractionation in trees, soils and fungi in a natural forest stand and a Norway spruce plantation. Ann. For. Sci. 64: 419-429. 